\title{
Chemical variability in the essential oil of leaves of Araçá (Psidium guineense Sw.), with occurrence in the Amazon
}

\author{
Pablo Luis B. Figueiredo ${ }^{1 *}$, Renan C. Silva ${ }^{2}$, Joyce Kelly R. da Silva ${ }^{3}$, Chieno Suemitsu ${ }^{4}$, Rosa Helena V. Mourão ${ }^{5}$ \\ and José Guilherme S. Maia'
}

\begin{abstract}
Background: Psidium guineense, known as Araçá, is a Brazilian botanical resource with commercial application perspectives, based on the functional elements of its fruits and due to the use of its leaves as an anti-inflammatory and antibacterial agent. The essential oils of leaves of twelve specimens of Araçá were analyzed by GC and GC-MS to identify their volatile constituents and associate them with the biological activities reputed to the plant.

Results: In a total of 157 identified compounds, limonene, $a$-pinene, $\beta$-caryophyllene, epi- $\beta$-bisabolol, caryophyllene oxide, $\beta$-bisabolene, $a$-copaene, myrcene, muurola-4,10(14)-dien-1- $\beta$-ol, $\beta$-bisabolol, and ar-curcumene were the primary components in descending order up to $5 \%$. Hierarchical Cluster Analysis (HCA) and Principal Component Analysis (PCA) displayed three different groups with the following chemical types: limonene/a-pinene, $\beta$-bisabolene/epi- $\beta$ bisabolol, and $\beta$-caryophyllene/caryophyllene oxide. With the previous description of another chemical type rich in spathulenol, it is now understood that at least four different chemotypes for P. guineense should occur.

Conclusions: In addition to the use of the Araçá fruits, which are rich in minerals and functional elements, it should be borne in mind that the knowledge of the chemical composition of the essential oils of leaves of their different chemical types may contribute to the selection of varieties with more significant biological activity.
\end{abstract}

Keywords: Psidium guineense, Myrtaceae, essential oil composition, chemical variability

\section{Background}

Myrtaceae comprises 132 genera and 5671 species of trees and shrubs, which are distributed mainly in tropical and subtropical regions of the world, particularly South America, Australia and Tropical Asia [1]. It is one of the most prominent families in Brazil, represented by 23 genera and 1034 species, with occurrence in all regions of the country [2,3]. Psidium is a genus with at least 60 to 100 species, occurring from Mexico and Caribbean to Argentina and Uruguay. Therefore, it is naturally an American genus, although $P$. guajava, $P$. guineense and $P$. cattleyanum are subtropical and tropical species in many other parts of the world [4].

\footnotetext{
*Correspondence: pablolbf@ufpa.br

1 Programa de pós-graduação em Química, Universidade Federal do Pará, 66075-900 Belém, PA, Brazil

Full list of author information is available at the end of the article
}

Psidium guineense Swartz [syn. Guajava guineensis (Sw.) Kuntze, Myrtus guineensis (Sw.) Kuntze, Psidium araca Raddi, $P$. guyanense Pers., P. laurifolium O. Berg, P. rotundifolium Standl., P. sprucei O. Berg, among others [5] (www.tropicos.org/Name/22102032) is a native shrub or small tree up to about $6 \mathrm{~m}$ high occurring in all Brazilian biomes, commonly known as Araçá. It has a berry-type fruit with yellow, red or purple peel and whitish pulp, rich in minerals and functional elements, such as vitamin $C$ and phenolic compounds [6-9]. The leaves and pulp of Araçá have been used as an anti-inflammatory remedy for wound healing and oral antibacterial agent $[10,11]$, as well as it presented antibacterial activity against pathogenic microorganisms [11-13]. Some essential oils of Araçá were previously described: Foliar oil from a specimen growing in Arizona, USA, with predominance of $\beta$-bisabolene, $\alpha$-pinene and limonene [14]; 
foliar oil from a specimen collected in Roraima, Brazil, with $\beta$-bisabolol, epi- $\alpha$-bisabolol and limonene as the main constituents [15]; and another foliar oil from a specimen sampled in Mato Grosso do Sul Brazil, where spathulenol was the primary volatile compound [16].

The present work aimed at investigating the variability of the chemical composition of the essential oils of different specimens of Psidium guineense, occurring in the Amazon region, to contribute to the knowledge of its chemical types.

\section{Experimental}

\section{Plant material}

The leaf samples of twelve Psidium guineense specimens were collected in Pará state, Brazil. Collection site and voucher number of each specimen are listed in Table 1. The plant vouchers after the identification were deposited in the Herbaria of Embrapa Amazônia Oriental, in Belém (IAN) and Santarém (HSTM), Pará state, Brazil. The leaves were dried for two days in the natural environment and, then, subjected to essential oil distillation.

\section{Isolation and analysis of the composition of oils}

The leaves were ground and submitted to hydrodistillation using a Clevenger-type apparatus $(3 \mathrm{~h})$. The oils were dried over anhydrous sodium sulfate, and their yields were calculated by the plant dry weight. The moisture content of the samples was calculated using an Infrared Moisture Balance for water loss measurement. The procedure was performed in duplicate.

Table 1 Identification data and collection site of the specimens of Psidium guineense

\begin{tabular}{|c|c|c|c|}
\hline Samples & Collection site & Herbarium $\mathrm{N}^{\circ}$ & Local coordinates \\
\hline PG-01 & Curuçá, PA, Brazil & IAN-195396 & $0^{\circ} 72^{\prime} 65^{\prime \prime} \mathrm{S} / 47^{\circ} 84^{\prime} 07^{\prime \prime} \mathrm{W}$ \\
\hline PG-02 & Curuçá, PA, Brazil & IAN-195397 & $0^{\circ} 43^{\prime} 40^{\prime \prime} \mathrm{S} / 47^{\circ} 50^{\prime} 58^{\prime \prime} \mathrm{W}$ \\
\hline PG-03 & Curuçá, PA, Brazil & IAN-195398 & $0^{\circ} 72^{\prime} 67^{\prime \prime} \mathrm{S} / 47^{\circ} 85^{\prime} 13^{\prime \prime} \mathrm{W}$ \\
\hline PG-04 & Curuçá, PA, Brazil & IAN-195399 & $0^{\circ} 72^{\prime} 57^{\prime \prime} \mathrm{S} / 47^{\circ} 84^{\prime} 84^{\prime \prime} \mathrm{W}$ \\
\hline PG-05 & Curuçá, PA, Brazil & IAN-195400 & $0^{\circ} 72^{\prime} 57^{\prime \prime} \mathrm{S} / 47^{\circ} 84^{\prime} 07^{\prime \prime} \mathrm{W}$ \\
\hline PG-06 & Santarém, PA, Brazil & HSTM-3611 & $2^{\circ} 27^{\prime} 48.7^{\prime \prime} \mathrm{S} / 54^{\circ} 44^{\prime} 04^{\prime \prime} \mathrm{W}$ \\
\hline PG-07 & $\begin{array}{l}\text { Monte Alegre, PA, } \\
\text { Brazil }\end{array}$ & HSTM-6763 & $\begin{array}{l}1^{\circ} 57^{\prime} 24.9^{\prime \prime} \\
\mathrm{S} / 54^{\circ} 07^{\prime} 07.8^{\prime \prime} \mathrm{W}\end{array}$ \\
\hline PG-08 & $\begin{array}{l}\text { Monte Alegre, PA, } \\
\text { Brazil }\end{array}$ & HSTM-6763 & $\begin{array}{l}1^{\circ} 57^{\prime} 24.9^{\prime \prime} \\
\mathrm{S} / 54^{\circ} 07^{\prime} 07.8^{\prime \prime} \mathrm{W}\end{array}$ \\
\hline PG-09 & Santarém, PA, Brazil & HSTM-6775 & $\begin{array}{l}2^{\circ} 25^{\prime} 14.6^{\prime \prime} \\
\quad \mathrm{S} / 54^{\circ} 44^{\prime} 25.8^{\prime \prime} \mathrm{W}\end{array}$ \\
\hline PG-10 & Santarém, PA, Brazil & HSTM-3603 & $\begin{array}{l}2^{\circ} 25^{\prime} 08.4^{\prime \prime} \\
\quad \mathrm{S} / 54^{\circ} 44^{\prime} 28.3^{\prime \prime} \mathrm{W}\end{array}$ \\
\hline PG-11 & Santarém, PA, Brazil & HSTM-6769 & $\begin{array}{l}2^{\circ} 29^{\prime} 16.8^{\prime \prime} \\
\quad \mathrm{S} / 54^{\circ} 42^{\prime} 07.9^{\prime \prime} \mathrm{W}\end{array}$ \\
\hline PG-12 & $\begin{array}{l}\text { Ponta de Pedras, PA, } \\
\text { Brazil }\end{array}$ & HSTM-6759 & $\begin{array}{l}2^{\circ} 31^{\prime} 08.3^{\prime \prime} \\
\mathrm{S} / 54^{\circ} 52^{\prime} 25.8^{\prime \prime} \mathrm{W}\end{array}$ \\
\hline
\end{tabular}

The oils were analyzed on a GCMS-QP2010 Ultra system (Shimadzu Corporation, Tokyo, Japan), equipped with an AOC-20i auto-injector and the GCMS-Solution software containing the NIST (Nist, 2011) and FFNSC 2 (Mondello, 2011) libraries [17, 18]. A Rxi-5ms (30 m x $0.25 \mathrm{~mm} ; 0.25 \mu \mathrm{m}$ film thickness) silica capillary column (Restek Corporation, Bellefonte, PA, USA) was used. The conditions of analysis were: injector temperature of $250{ }^{\circ} \mathrm{C}$; Oven temperature programming of $60-240{ }^{\circ} \mathrm{C}$ $\left(3{ }^{\circ} \mathrm{C} / \mathrm{min}\right)$; Helium as carrier gas, adjusted to a linear velocity of $36.5 \mathrm{~cm} / \mathrm{s}(1.0 \mathrm{~mL} / \mathrm{min})$; split mode injection for $1 \mu \mathrm{L}$ of sample (oil $5 \mu \mathrm{L}$ : hexane $500 \mu \mathrm{L}$ ); split ratio 1:20; ionization by electronic impact at $70 \mathrm{eV}$; ionization source and transfer line temperatures of 200 and $250{ }^{\circ} \mathrm{C}$, respectively. The mass spectra were obtained by automatic scanning every $0.3 \mathrm{~s}$, with mass fragments in the range of $35-400 \mathrm{~m} / \mathrm{z}$. The retention index was calculated for all volatile components using a homologous series of C8-C20 n-alkanes (Sigma-Aldrich, USA), according to the linear equation of Van den Dool and Kratz (1963) [19]. The quantitative data regarding the volatile constituents were obtained by peak-area normalization using a GC 6890 Plus Series, coupled to FID Detector, operated under similar conditions of the GC-MS system. The components of oils were identified by comparing their retention indices and mass spectra (molecular mass and fragmentation pattern) with data stored in the GCMSSolution system libraries, including the Adams library (2007) [20].

\section{Statistical analysis}

The multivariate analysis was performed using as variables the constituents with content above than 5\%. For the multivariate analysis, the data matrix was standardized by subtracting the mean and then dividing it by the standard deviation. For hierarchical cluster analysis, the complete linkage method and the Euclidean distance were used. Minitab software (free 390 version, Minitab Inc., State College, PA, USA), was used for these analyzes.

\section{Results and discussion}

Yield and composition of the oils

Psidium guineense is a botanical resource that presents commercial application perspectives, based on its fruits and functional elements, as well as due to the use of its leaves as anti-inflammatory and antibacterial agent [614]. For this study were selected twelve Araçá specimens, with occurrence in various localities of Pará state (PA), Brazil (see Table 1), and which showed different composition for the leaf oils. The yields of the oils from these twelve Araçá samples ranged from 0.1 to $0.9 \%$, where the higher yields were from specimens sampled in the Northeast of Pará, Brazil (0.4-0.9\%), and the lower yields were 
from plants collected in the West of Pará, Brazil (0.1$0.3 \%)$. The identification of the constituents of the oils by GC and GC-MS was $92.5 \%$ on average, with a total of 157 compounds, where limonene (0.3-47.4\%), $\alpha$-pinene (0.1$35.6 \%), \beta$-caryophyllene (0.1-24.0\%), epi- $\beta$-bisabolol (6.5$18.1 \%)$, caryophyllene oxide $(0.3-14.1 \%), \beta$-bisabolene (0.1-8.9\%), $\alpha$-copaene (0.3-8.1\%), myrcene (0.1-7.3\%), muurola-4,10(14)-dien-1- $\beta$-ol $\quad(1.6-5.8 \%), \quad \beta$-bisabolol (2.9-5.6\%), and ar-curcumene (0.1-5.0\%) were the primary components, in descending order up to $5 \%$ (see Figure 1 and Table 2). In general, the constituents identified in oils belong to the terpenoids class, with the following predominance: monoterpene hydrocarbons (0.9-76.9\%), oxygenated sesquiterpenes (5.2-63.5\%), sesquiterpene hydrocarbons (5.6-46.7\%), and oxygenated monoterpenes (1.9-8.8\%).

Comparing these results with the composition of other essential oils described for the same plant, a specimen of $P$. guineense sampled in Arizona, USA, has also been found to contain $\beta$-bisabolene, $\alpha$-pinene, and limonene as its primary constituents [14]. In addition, the oil from another specimen collected in Roraima, Brazil, presented $\beta$-bisabolol as the main component, followed by

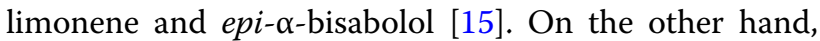
a specimen sampled in Mato Grosso do Sul, Brazil, presented an essential oil with a very high value of spathulenol [16]. Therefore, it is possible that there is a significant variation in the essential oils of different types of Araçá.

\section{Variability in oils composition}

The multivariate analysis of PCA (Principal Component Analysis) (Fig. 2) and HCA (Hierarchical Cluster Analysis) (Fig. 3) were applied to the primary constituents present in oils (content $\geq 5.0 \%$ ), for the evaluation of chemical variability among the $P$. guineense specimens.

The HCA analysis performed with complete binding and Euclidean distance showed the formation of three different groups. These were confirmed by the PCA analysis, which accounted for $79.5 \%$ of the data variance. The three groups were classified as:

Group I Characterized by the presence of the monoterpenes $\alpha$-pinene (13.4-35.6\%) and limonene (3,7-37,2\%),

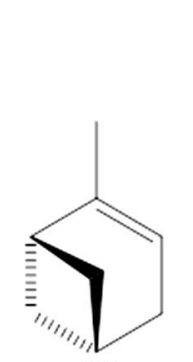

(1)

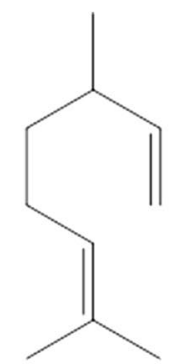

(2)<smiles>C=C(C)C1CC=C(C)CC1</smiles>

(3)

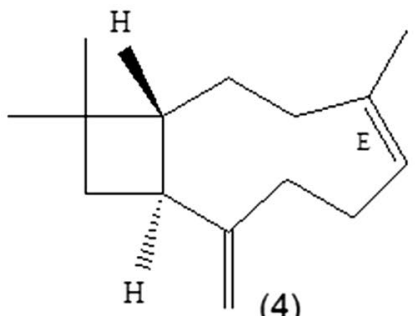

(4)
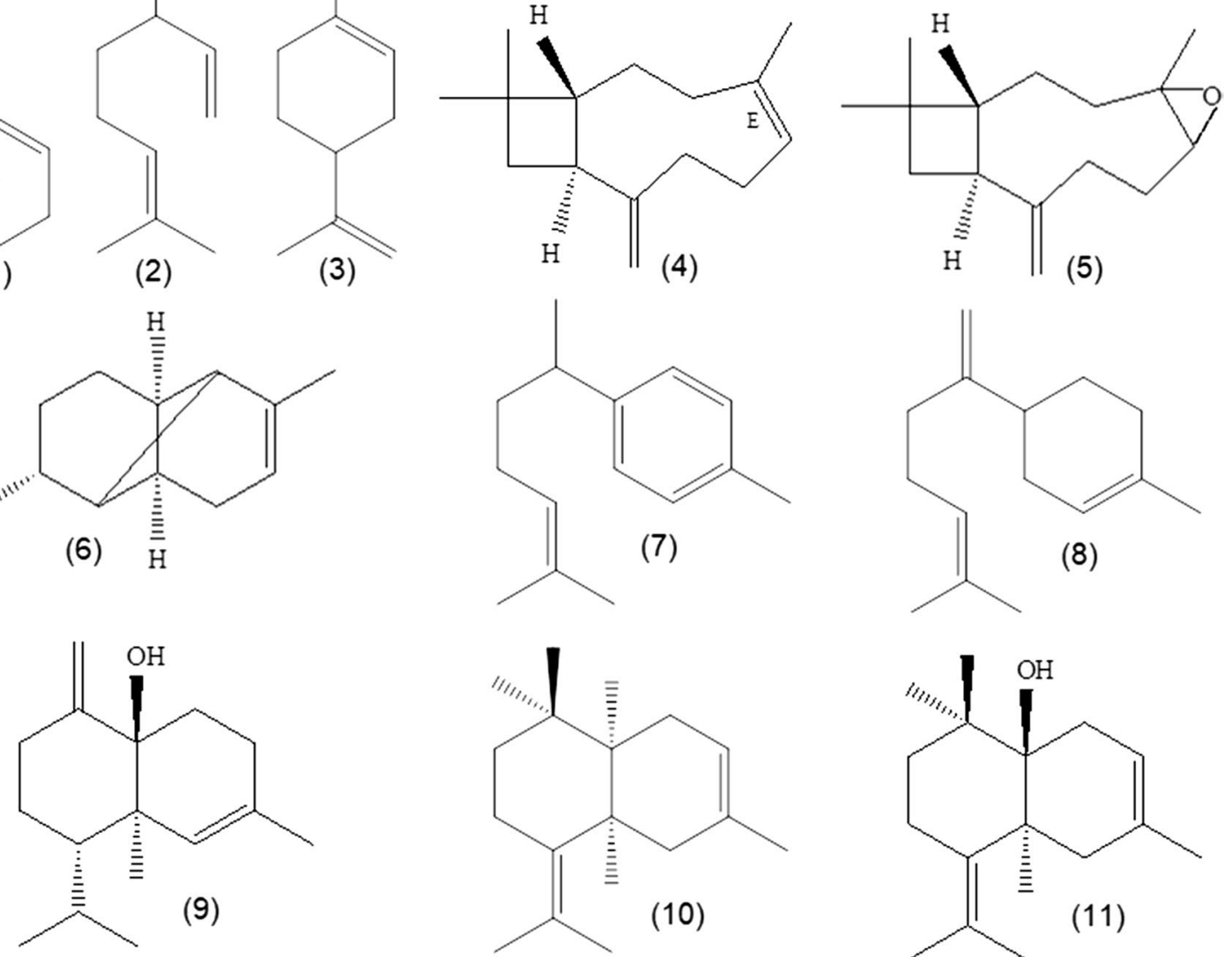

Fig. 1 Main constituents identified in the oils of P. guineense: (1) a-pinene, (2) myrcene, (3) limonene, (4) $\beta$-caryophyllene, (5) caryophyllene oxide, (6) a-copaene, (7) ar-curcumene, (8) $\beta$-bisabolene, (9) muurola-4,10(14)-dien-1- $\beta$-ol, (10) epi- $\beta$-bisabolol, (11) $\beta$-bisabolol 


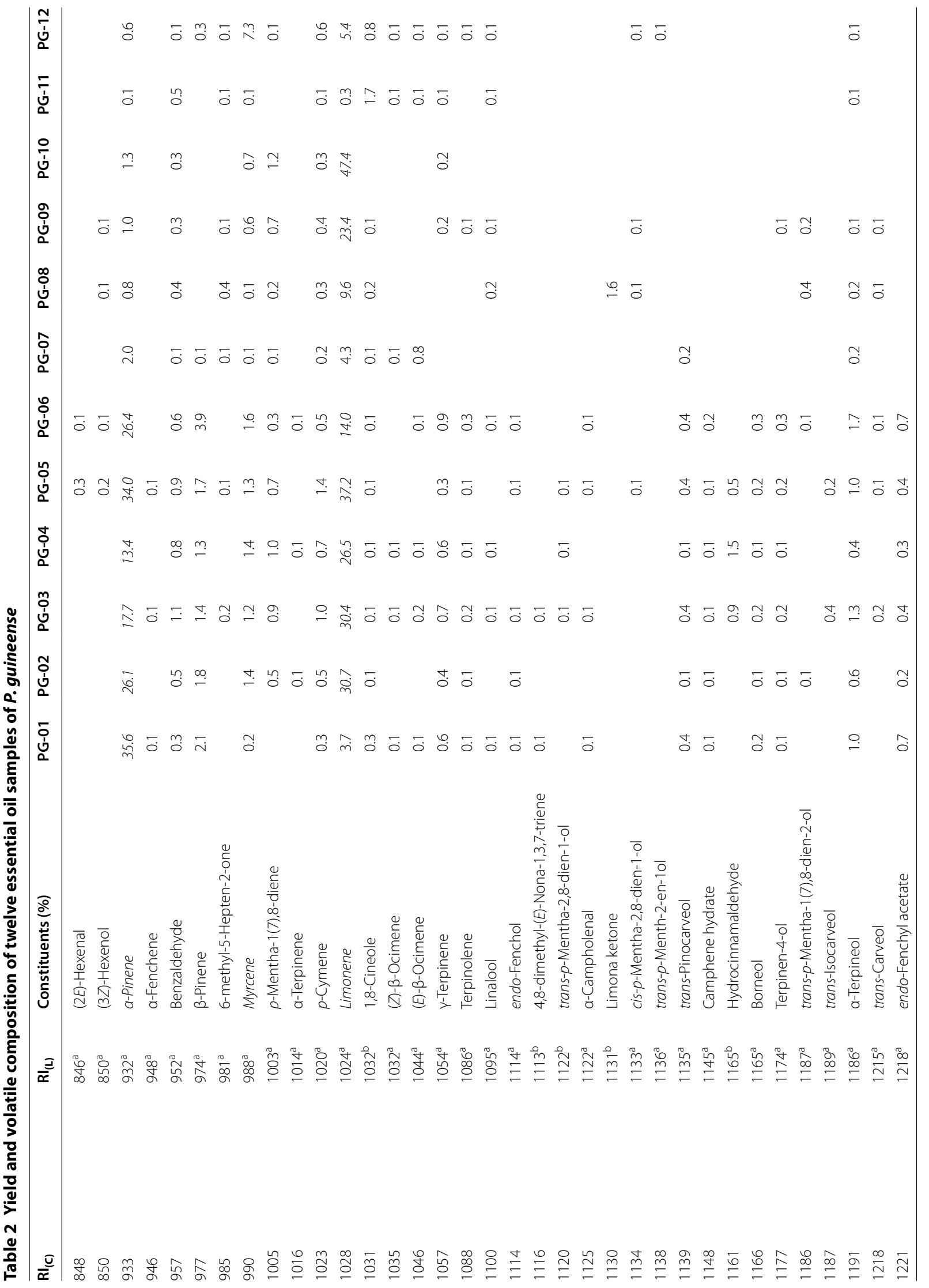




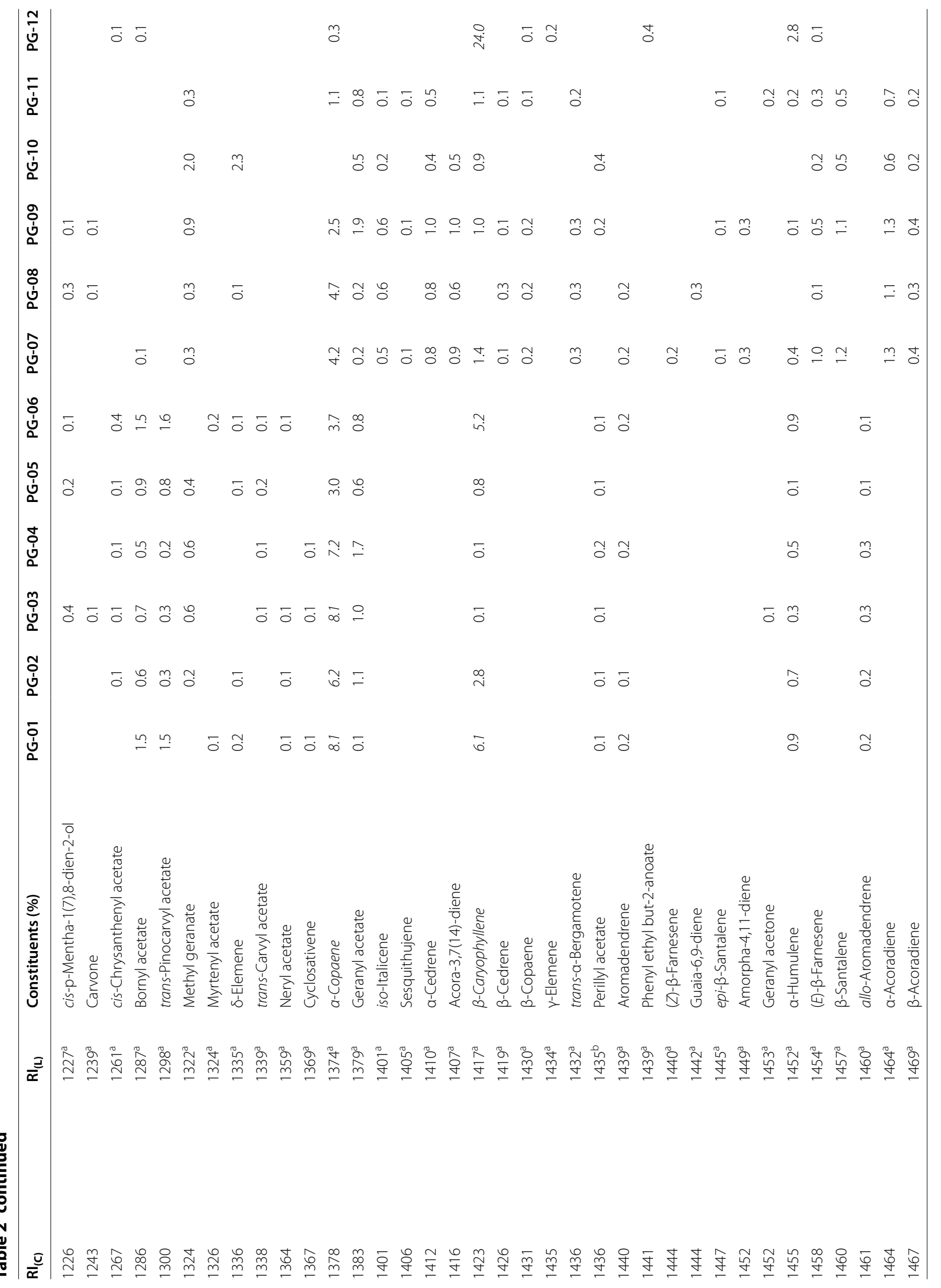




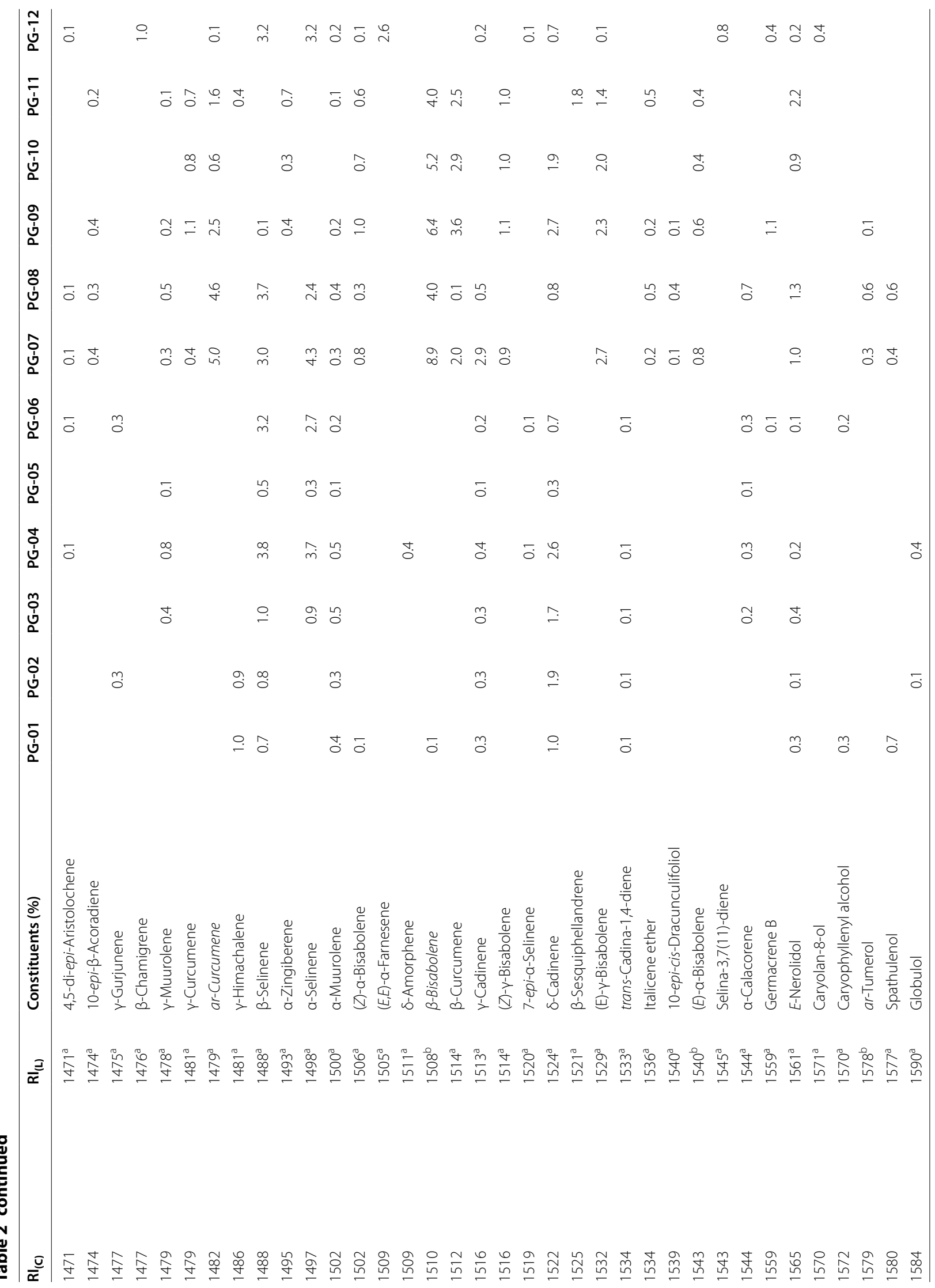




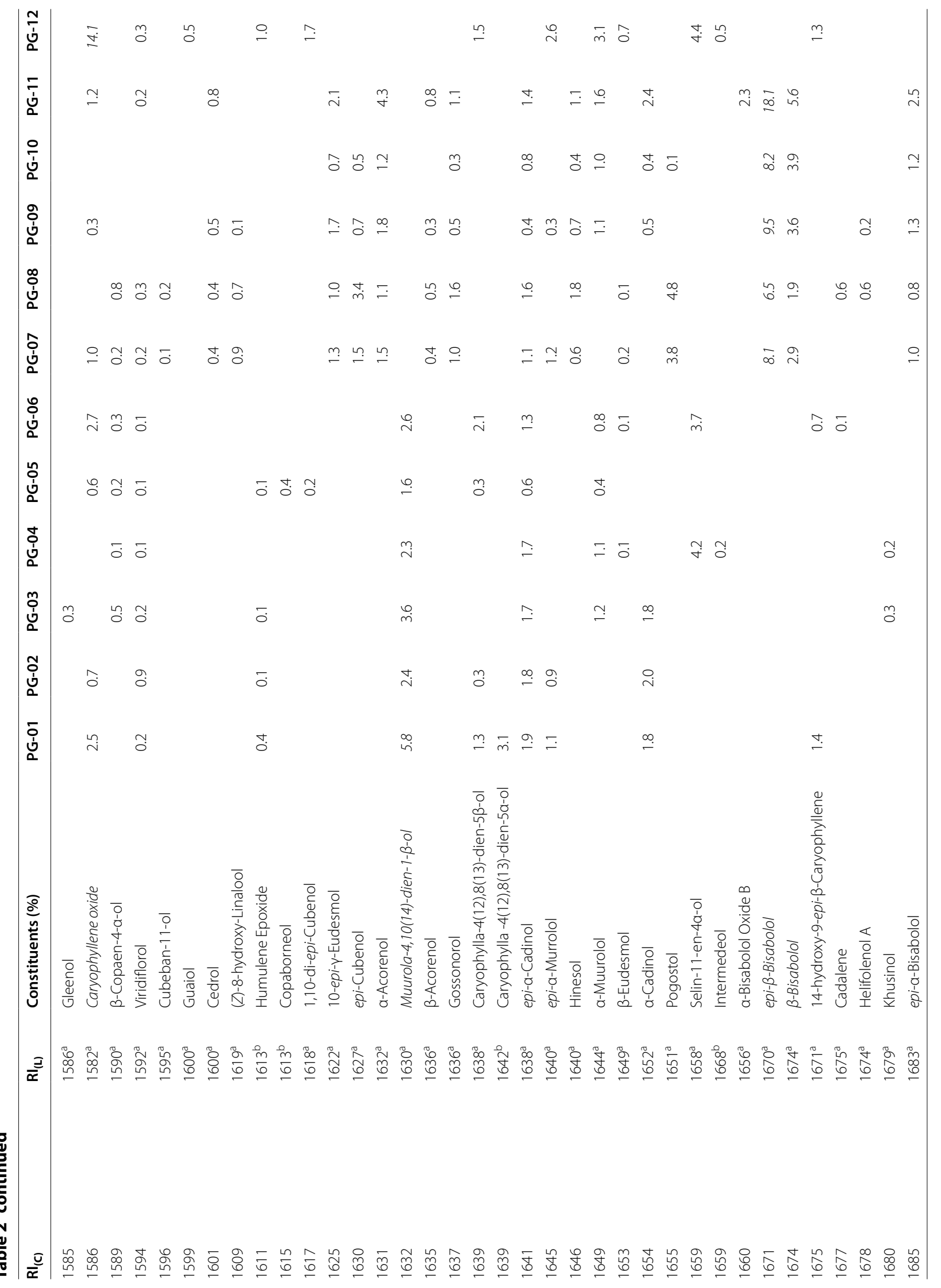




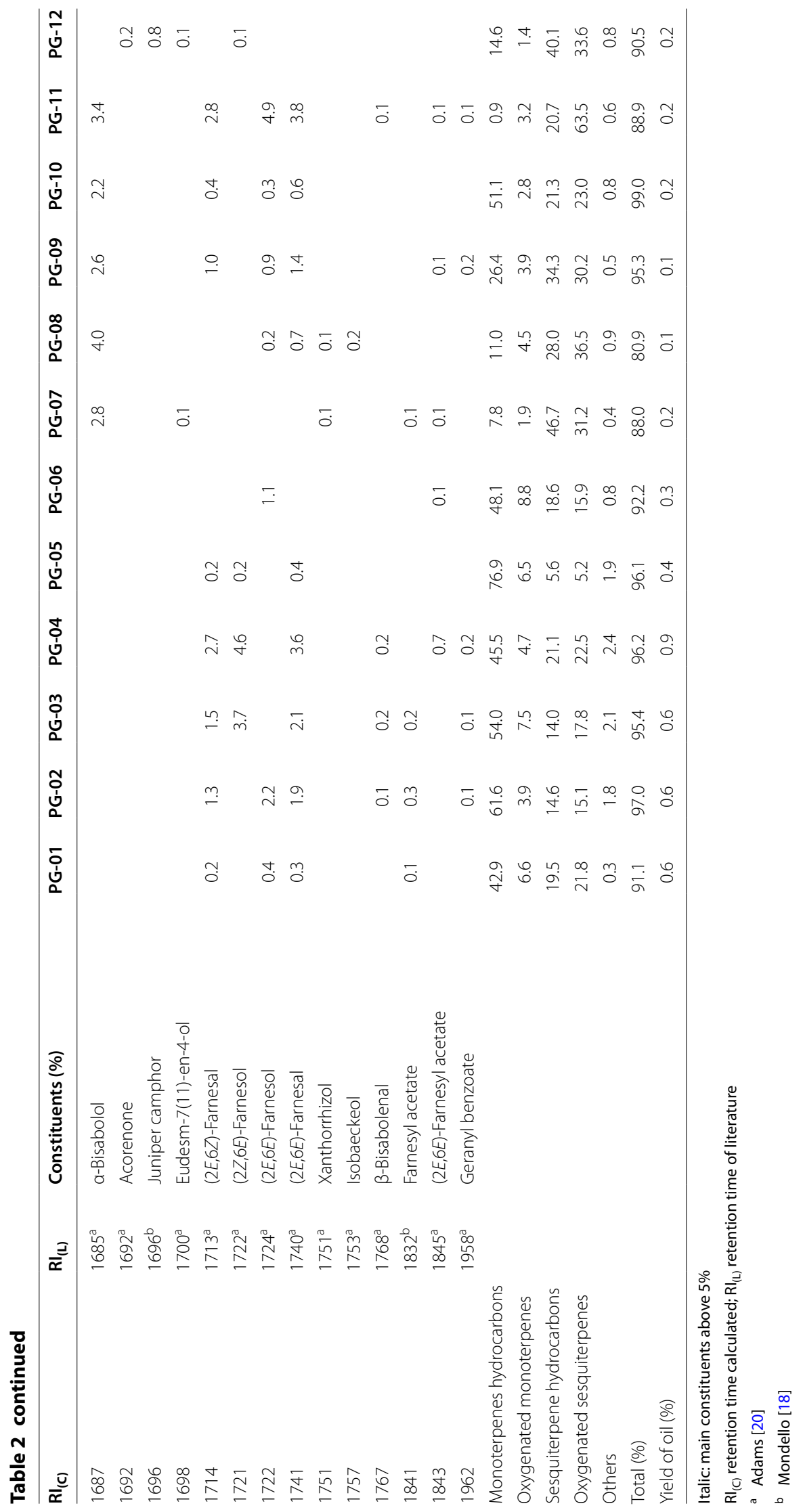




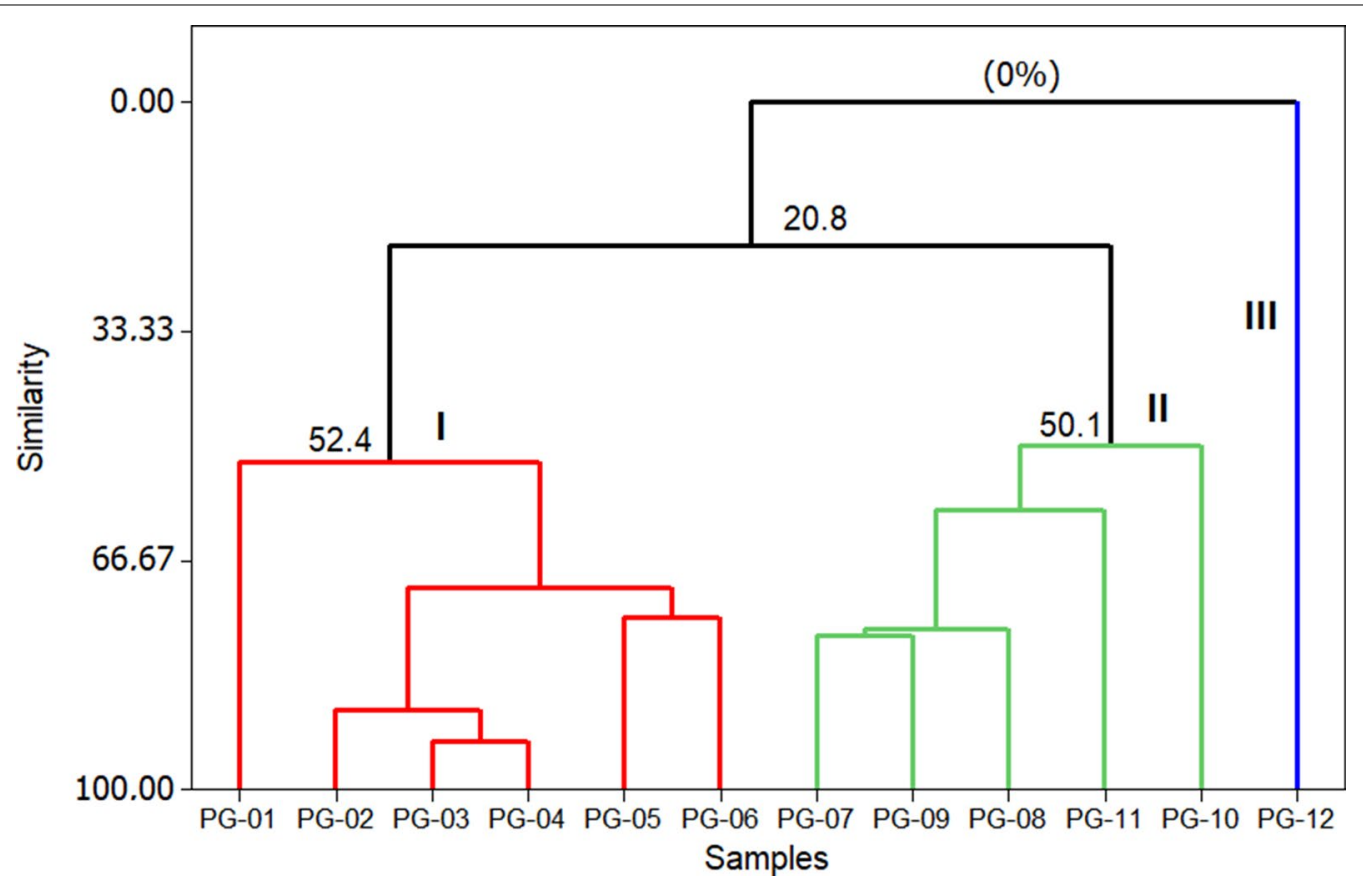

Fig. 2 Dendrogram representing the similarity relation in the oils composition of P. guineense

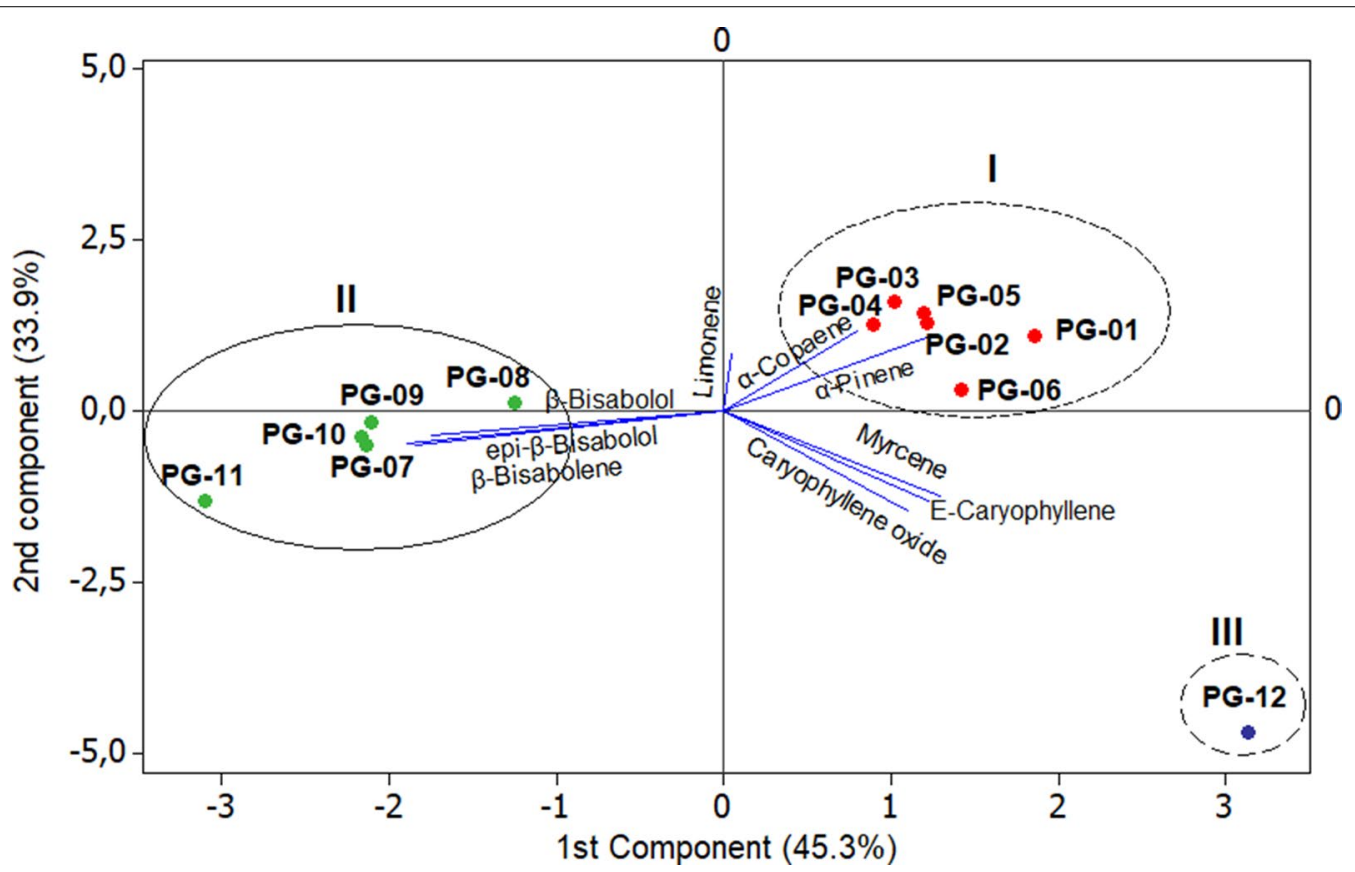

Fig. 3 Biplot (PCA) resulting from the analysis of the oils of $P$. guineense

composed by the specimens PG-01 to PG-06, collected in Curuçá (PG -01 to PG-05) and Santarém (PG-06), Pará state, Brazil, with $49.2 \%$ similarity between the samples.
Group II Characterized by the presence of the sesquiterpenes $\beta$-bisabolene (4.0-8.9\%) and epi- $\beta$-bisabolol (6.5-18.1\%), consisting by PG-07 to PG-10 specimens 
collected in Monte Alegre (PG-07 and PG-08) and Santarém (PG-09 and PG-10), Pará State, Brazil, with 50.3\% similarity between samples.

Group III Characterized by the presence of a significant content of $\beta$-caryophyllene (24.0\%) and caryophyllene oxide (14.1\%), constituted by the PG-12 specimen, collected in the city of Ponta de Pedras, Pará state, Brazil, which presented zero\% similarity with the other groups.

Thus, based on the study of these essential oils, the multivariate analysis (PCA and HCA) has suggested the existence of three chemical types among the twelve specimens of $P$. guineense collected in different locations of the Brazilian Amazon. It would then be the chemical types $\alpha$-pinene/limonene (Group I), $\beta$-bisabolene/epi$\beta$-bisabolol (Group II) and $\beta$-caryophyllene/caryophyllene oxide (Group III). Taking into account that two essential oils with a predominance of $\alpha$-pinene/ limonene and $\beta$-bisabolene/epi- $\beta$-bisabolol, respectively, were previously described $[14,15]$, it is understood that adding these two chemical types to that one rich in $\beta$-caryophyllene + caryophyllene oxide, which was a product of this study, besides the other chemical type with a high value of spathulenol, before reported by Nascimento and colleagues (2018) [16], will be now, at least, four chemical types known for the P. guineense essential oils.

Several studies have demonstrated the antiinflammatory activities of limonene, $\alpha$-pinene and $\beta$-caryophyllene, the primary constituents found in the oils of $P$. guineense presented in this paper. Limonene showed significant anti-inflammatory effects both in vivo and in vitro, suggesting a beneficial role as a diet supplement in reducing inflammation [21]; limonene decreased the infiltration of peritoneal exudate leukocytes and reduced the number of polymorphonuclear leukocytes, in the induced peritonitis [22]. $\alpha$-Pinene presented antiinflammatory effects in human chondrocytes, exhibiting potential anti-osteoarthritic activity [23], and in mouse peritoneal macrophages induced by lipopolysaccharides [24], being, therefore, a potential source for the pharmaceutical industry. The anti-arthritic and the in vivo antiinflammatory activities of $\beta$-caryophyllene was evaluated by molecular imaging [25].

\section{Conclusion}

In addition to the great use of the fruits of P. guineense, which are rich in minerals and functional elements, it is understood that the knowledge of the chemical composition of the essential oils of leaves of their different chemical types may contribute to the selection of varieties with more significant biological activity. The study intended to address this gap.

\section{Abbreviations}

HCA: Hierarchical Cluster Analysis; PCA: Principal Component Analysis; GC: Gas chromatography; GC-MS: Gas chromatography-Mass spectrometry; IAN: Herbarium of Embrapa Amazônia Oriental; HSTM: Herbarium of Santarém.

\section{Authors' contributions}

PLBF participated in the collection and preparation the plants to the herbaria, run the laboratory work, analyzed the data and contributed to the drafted paper. RCS helped with lab work. JKRS guided the lab work and data analysis. CS identified the plants and managed their introduction in herbaria. RHVM helped with lab work and data analysis. JGSM proposed the work plan, guided the laboratory work and drafted the manuscript. All authors read and approved the final manuscript.

\section{Author details \\ ${ }^{1}$ Programa de pós-graduação em Química, Universidade Federal do Pará, 66075-900 Belém, PA, Brazil. ${ }^{2}$ Faculdade de Química, Universidade Federal do Pará, Belém, PA, Brazil. ${ }^{3}$ Programa de Pós-Graduação em Biotecnologia, Universidade Federal do Pará, Belém, PA, Brazil. ${ }^{4}$ Laboratório de Botânica, Universidade Federal do Oeste do Pará, Santarém, PA, Brazil. ${ }^{5}$ Laboratório de Bioprospecção e Biologia Experimental, Universidade Federal do Oeste do Pará, Santarém, PA, Brazil.}

\section{Acknowledgements}

The authors would like to thank CAPES, a Brazilian Government's research funding agency, for its financial support.

\section{Competing interests}

The authors declare that they have no competing interests.

Ethics approval and consent to participate

Not applicable.

\section{Publisher's Note}

Springer Nature remains neutral with regard to jurisdictional claims in published maps and institutional affiliations.

Received: 26 February 2018 Accepted: 30 April 2018

Published online: 10 May 2018

\section{References}

1. Govaerts R, Sobral M, Ashton P, Barrie F, Holst B, Landrum L, Lucas E, Matsumoto K, Mazine F, Proença C, Soares-Silva L, Wilson P, Niclughdha E: World checklist of selected plant families - Myrtaceae. Kew: The Board of Trustees of the Royal Botanic Gardens; 2013. http://wcsp.science.kew.org.

2. Landrum LR, Kawasaki ML (1997) The genera of Myrtaceae in Brazil: an illustrated synoptic treatment and identification keys. Brittonia 49:508-536

3. Sobral M, Proença C, Souza M, Mazine F, Lucas E: Myrtaceae. Lista de espécies da flora do Brasil. Rio de Janeiro: Jardim Botânico do Rio de Janeiro; 2015. http://floradobrasil.jbrj.gov.br.

4. Landrum LR (2017) The genus Psidium (Myrtaceae) in the state of Bahia, Brazil. Canotia 13:1-101

5. Missouri Botanical Garden. www.tropicos.org/Name/22102032.

6. Caldeira SD, Hiane PA, Ramos MIL, Ramos Filho MM (2004) Caracterização físico-química do Araçá (Psidium guineense Sw.) e do Tucumá (Vitex cymosa Bert.) do Estado de Mato Grosso do Sul. B CEPPA 22:145-154

7. Genovese MI, Pinto MS, Gonçalves AESS, Lajolo FM (2008) Bioactive compounds and antioxidant capacity of exotic fruits and commercial frozen pulps from Brazil. Food Sci Technol Int 14:207-214

8. Gordon A, Jungfer E, da Silva BA, Maia JGS, Marx F (2011) Phenolic constituents and antioxidant capacity of four underutilized fruits from the Amazon region. J Agric Food Chem 59:7688-7699

9. Rivero-Maldonado G, Pacheco D, Martín LM, Sánchez-Urdaneta A, Quirós M, Ortega J, Colmenares C (2013) Bracho B (2013) Flavonoides presentes en especies de Psidium (Myrtaceae) de Venezuela. Rev Fac Agron $30: 217-230$ 
10. Di Stasi LC, Oliveira GP, Carvalhaes MA, Queiroz-Junior M, Tien OS, Kakimari SH, Reis MS (2002) Medicinal plants popularly used in the Brazilian Tropical Atlantic Forest. Fitoterapia 73:69-91

11. Vieira TI, Gondim BLC, Santiago BM, Valença AMG (2012) In vitro antibacterial and non-stick activity of extracts from leaves of Psidium guineense Sw. and Syzygium cumini (L.) Skeels on oral microorganisms. Rev Gaúcha Odontol 60:359-365

12. Anesini C, Perez C (1993) Screening of plants used in Argentine folk medicine for antimicrobial activity. J Ethnopharmacol 39:119-128

13. Fernandes TG, Mesquita ARC, Randau KP, Franchitti AA, Ximenes EA (2012) In vitro synergistic effect of Psidium guineense (Swartz) in combination with antimicrobial agents against methicillin-resistant Staphylococcus aureus strains. Sci World J 158237:7p

14. Tucker O, Maciarelloa MJ, Landrumb LR (1995) Volatile leaf oils of American Myrtaceae. III. Psidium cattleianum Sabine, P. friedrichsthalianum (Berg) Niedenzu, P. guajava L., P. guineense Sw., and P. sartorianum (Berg) Niedenzu. J Essent Oil Res 7:187-190

15. da Silva JD, Luz AIR, da Silva MHL, Andrade EHA, Zoghbi MGB, Maia JGS (2003) Essential oils of leaves and stems of four Psidium spp. Flav Fragr J $18: 240-243$

16. do Nascimento KF, Moreira FMF, Santos JA, Kassuia CAL, Croda JHR, Cardoso CAL, Vieira MC, Ruiz ALTG, Foglio MA, de Carvalho JE, Formagio ASN (2017) Antioxidant, anti-inflammatory, antiproliferative and antimycobacterial activities of the essential oil of Psidium guineense Sw and spathulenol. J Ethnopharmacol 210:351-358

17. NIST - National Institute of Standards and Technology (2011) Mass Spectral Library (NIST/EPA/NIH, v.2.0d). The NIST Mass Spectrometry Data Center, Gaithersburg.
18. Mondello $L$ (2011) Flavors and fragrances of natural and synthetic compounds, Mass Spectral Database (FFNSC 2). John Wiley \& Sons Inc, New York

19. Van Den Dool H, Kratz PDJA (1963) Generalization of the retention index system including linear temperature programmed gas-liquid partition chromatography. J Chromatogr A 11:463-471

20. Adams RP (2007) Identification of essential oil components by gas chromatography/mass spectrometry. Allured Publishing Corporation, Carol Stream

21. d'Alessio PA, Ostan R, Bisson J-F, Schulzke JD, Ursini MV, Béné MC (2013) Oral administration of $d$-limonene controls inflammation in rat colitis and displays anti-inflammatory properties as diet supplementation in humans. Life Sci 92:1151-1156

22. Kummer R, Estevão-Silva CF, Bastos RL, Rocha BA, Spironello RA, Yamada AN, Bersani-Amado CA, Cuman RKN (2015) Alpha-pinene reduces in vitro and in vitro leukocyte migration during acute inflammation. Int Journal applied Res Nat Prod 8:12-17

23. Rufino AT, Ribeiro M, Judas F, Salgueiro L, Lopes MC, Cavaleiro C, Mendes AF (2014) Anti-inflammatory and chondroprotective activity of (+)-pinene structural and enantiomeric selectivity. J Nat Prod 77:264-269

24. Kim DS, Lee HJ, Han YH, Kee JY, Kim HJ, Shin HJ, Lee BS, Kim SH, Kim SJ, Park SH, Choi BM, Park SJ, Um JY, Hong SH (2015) Alpha-pinene exhibits anti-inflammatory activity through the suppression of MAPKs and the NF-kB pathway in mouse peritoneal macrophages. Am J Chin Med 43:731-742

25. Dahham SS, Tabana YM, Khadeer Ahamed MB, Abdul Majid AMS (2015) In vivo anti-inflammatory activity of $\beta$-caryophyllene, evaluated by molecular imaging. Molecules \& Medicinal Chemistry 1(e1001):6p

\section{Submit your manuscript to a SpringerOpen ${ }^{\circ}$ journal and benefit from:}

- Convenient online submission

- Rigorous peer review

- Open access: articles freely available online

- High visibility within the field

- Retaining the copyright to your article

Submit your next manuscript at $\boldsymbol{\nabla}$ springeropen.com 